\title{
The Influence of Corporate Social Responsibility, Business Diversification, and Company Size upon Company Value
}

\author{
Erni Masdupi ${ }^{1 *}$, Ananda Yulius ${ }^{1}$ \\ ${ }^{1}$ Economics Faculty, Universitas Negeri Padang \\ Email: emasdupi@gmail.com
}

\begin{abstract}
The purpose of a company is to maximize company value, which is synonymous to increasing the shareholders' wealth. There are some variables that could determine company value such as corporate social responsibility (CSR), diversification of business, and company size. This study examines the influence of corporate social responsibility (CSR), diversification of business, and size of the company upon the value of manufacturing companies listed on the Indonesian Stock Exchange (IDX). The research population is all manufacturing companies listed on IDX within the period 2011-2014. Based on some purposive sampling criteria, 110 company-year observations were chosen as the sample for this study. This study used a regression model, which found that CSR had an insignificant effect in influencing campany value. Diversification, as measured in the Herfindahl index by sales, had a positive and significant effect on company value, but the number of business segments had an insignificant impact upon company value. Finally, company size, which was measured by the number of assets, insignificantly affected company value while the market value of equity positively and significantly influenced company value. This implied that investors trust market value more than historical data. This is because market measurements such as the market value of equity could reflect a company's prospects in the future while accounting-based measures only provide historical data on the company. Additionally, the government should allow companies to grow in size and to diversify into related businesses.
\end{abstract}

\section{Type of Paper: Empirical}

Keywords: Corporate social responsibility; business diversification; company size and company value

\section{Introduction}

Financial management argues that the main goal of a company goal is to maximize its own value, which is the same as increasing the shareholders' wealth. Therefore, a company must have good value. There are some variables that could determine company value such as corporate social responsibility (CSR), diversification of business, and company size.

The World Business Council for Sustainable Development (WBCSD) stated that Corporate Social Responsibility (CSR) is a company's commitment to contribute to sustainable economic development. It could be fullfilled through cooperation with the employees and their families, 
local communities, and the general public to improve the quality of life in ways that benefit both the beneficiaries and business development (Ghelli, 2010). Visser et al., (2010) argued that a company's role is not only as a business entity that pursues good financial performance but also as a good corporate citizen. This means that a company also has responsibilities in social and environmental aspects. It is argued that a company has rights, obligations, and responsibilities to the society as well as to other citizens. Moreover, social responsibility might increase benefits in long term and support the continuity of a business (Ho, 2010). Some previous studies showed that there is a positive relationship between the CSR and the value of company (Aggarwal, 2013; Bidhari et al., 2013; Barnet and Salomon, 2011; Ghelli, 2013; Margolis et al., 2009; Tilakasiri, 2012; Vijfvinkel et al., 2011).

Diversification of business could affect company value through the internal capital market, where divisions with high cash flows but poor investment opportunities could finance divisions with low cash flows but excellent investment opportunities. Diversified companies may have less need to depend on the external capital market, as they may be able to channel funds from divisions with excess funds to divisions with deficient funds at a lower cost (Williamson, 1975, 1985). Kock and Guillen (2001) noted that the effect of corporate diversification will be different across countries because of the influence of the institutional environment in the country where the diversification takes place. Khanna and Palepu (1997), and Lins and Servaes (2002) stated that the internal capital market would have more substantial benefits for companies in less institutionally developed economies than to companies in more institutionally developed economies.

Company size is also a determinant of company value. A larger company is usually more established and it is assumed that it could operate effectively and outperform a smaller company. Driffield, Mahambare and Pal (2007), Gupta (1969), and Lang and Stulz (1994) said that a larger company generally has a good performance compared to smaller companies because the former could reap the benefits of easy access to funds, economies of scale, and skilled employees.

This study is conducted to achieve a number of objectives: (1) to determine whether corporate social responsibility affects company value; (2) to investigate whether diversification of business, which is measured with the Herfindahl index by sales and the number of business segments, determines company value; and (3) to analyze the influence of company size (proxied by the natural log of total asset and the market value of equity) upon company value.

\section{Literature Review}

\subsection{Stakeholder Theory}

The stakeholder theory is related to the theory of organizational management and business ethics. This theory explains the roles of capital and value in managing an organization. Theoritically speaking, the only important thing for a company is the shareholders. The purpose of a company is not only to maximize the shareholders' wealth but also the stakeholders'. The company has a responsiblity to achieve its needs, which is increasing the value for shareholders. However, the stakeholder theory states that the company has to consider the interests of other parties such as the employees, customers, supplier, investors, the society, and the government (Freeman, 2001). 


\subsection{Legitimacy Theory}

Suchman (1995) stated that legitimacy is the general perception that a company's action complies with existing value systems or social norms. Similarly, Susilowati (2013) explained that a company implements social and environmental responsibility in order to gain legitimacy from the society in relation to its business activities. A company does not only pay attention to the rights of the investors but also of the public.

\subsection{Signaling Theory}

The signaling theory was developed to explicitly account for the fact that corporate insiders (officers and directors) are generally much better informed about the current workings and future prospects of a company than outside investors. In the presence of asymmetric information, it is very difficult for investors to objectively discriminate between high-quality and low-quality companies. (Megginson, 1995) noted that:

“... statement by corporate managers conveys no useful information. Both 'bad and good' company managers will claim to have excellent growth and profitability prospects and, only the passage of time will prove who was correct, low-company quality insiders could profit by making false claims if these claims are believed by investors. Because of this asymmetric information problem, however, investors will assign a low average quality evaluation to shares of all companies. In the language of signaling theory, this is referred to as a pooling equilibrium since both high and low-quality companies are related to the same valuation "pool"...." (p.19).

\subsection{Agency Theory}

Jensen and Meckling (1976) defined an agency relationship as “... a contract under which one or more persons [principal(s)] engage another person (the agent) to perform some services on their behalf which involves delegating some decision making authority to the agent" ( $p .5)$. Based on this definition, an owner hires an agent to act in the owner's interests. It is expected that the agent would utilize the company resources efficiently in order to improve value. In reality, however, an agent does not always act in the principal's best interests because the owner could diversify his/her investments while the manager is limited to his/her human capital only

\subsection{Internal Capital market Theory}

Lins and Servaes (2002) stated that corporate diversification could affect company value in two ways. Firstly, the use of internal capital market hypothesis could result in higher values for diversified companies. Internal capital market refers to an arrangement where divisions with high cash flows can finance divisions with low cash flows; tis in turn has effect on a company's value. Furthermore, the internal capital market hypothesis postulates that diversification provides greater benefits for companies operating in less institutionally developed environments (Chakrabarti, Singh, \& Mahmood, 2007), such as Indonesia.

\section{Research Methodology}

This study employed secondary data from the annual reports of listed manufacturing 
Table 1. Variables in this study and their measurement

\begin{tabular}{|c|c|}
\hline Variable & Description \\
\hline $\begin{array}{l}\text { Company value } \\
\text { (Tobin's Q)it) }\end{array}$ & $\begin{array}{l}\text { Company value is measured by Tobin's } Q \text {. } \\
\text { Tobin 's } Q=\frac{\text { market value of equity }+ \text { total debt }}{\text { total asset }}\end{array}$ \\
\hline $\begin{array}{l}\text { Corporate Social } \\
\text { Responsibility } \\
\text { (CSR) }\end{array}$ & $\begin{array}{l}\text { corporate social responsibility is measured by disclosure index. } 0 \leq \mathrm{CSRI} \leq 1 \text {. Value } 1 \text { indicates disclosure and } 0 \\
\text { is non-disclosure. There are } 78 \text { items of CSR } \\
C S R D I=\sum x j\end{array}$ \\
\hline $\begin{array}{l}\text { Business } \\
\text { Diversification } \\
\text { HI_Sales }\end{array}$ & $\begin{array}{l}\quad \frac{N j}{\text { Business diversification is represented through the Herfindahl index by sales and the number of business }} \\
\text { segments. } \\
\text { Herfindahl index by sales is the sum of squared value of sales per segment as a fraction of company sales (Lang } \\
\text { \& Stultz, 1994), a value of } 1 \text { indicates an undiversified company and a value close to zero shows a diversified } \\
\text { company. }\end{array}$ \\
\hline NoSegment & $\begin{array}{l}\text { Segment is the number of business segments in a company (Berger \& Ofek, 1995; Chen \& Ho, 2000; Denis et al., } \\
\text { 1997; Lang \& Stultz, 1994). }\end{array}$ \\
\hline Company size & Company size is manifested by the natural log of total assets and the natural $\log$ of the market value of equity. \\
\hline LnAssets & LnAssets is the natural log of total assets (Li et al., 2006; mitton, 2002; Serrano-Cinca et al., 2007) \\
\hline LnMVE & LnMVE is measured as the natural log of market value of equity (Kumar, 2005; Mitton, 2002; Titman \& Wessel, 1988) \\
\hline $\mathrm{e}$ & ${ }^{-1}$ \\
\hline
\end{tabular}

companies on the IDX from the end of the 2011 to 2014 financial years. Based on the purposive sampling, 88 company-year observations were selected with the following set of criteria: (1) the availability of financial statements during the analysis period that included market value of equity, total debt, total assets, sales, the number of business segments, and corporate social responsibility. This study uses a regression model with company value (Tobin's Q) as a dependent variable. Tobin's $Q$ was used to measure company value since this proxy combines market-based measurements and accounting-based measurements. The independent variables include corporate social responsibility, diversification of business (HI_Sales, HI_Assets, and NoSegment), and company size (LnAssets and LnMVE). Therefore, this study has five independent variables. The measurement of each variable is described in Table 1.

\section{4. $\quad$ Results}

\subsection{Descriptive statisics}

There were 88 company-year case data during the period of analysis from 2011 to 2014 (Tabel 2 ). According to the descriptive statistics as shown in Table 2, the mean of Tobin's Q was quite good with a mean value of $247 \%$ (2.47) while corporate social responsibility among manufacturing companies listed on IDX was quite low with an average value of 0.20 . This indicated that the companies' value was rather good but their corporate social responsibility was rather low.

This study also provided evidence that the mean values of Herfindahl index by sales (HISales) and the number of business segments were 0.65 and 3.42, respectively. It means that, on average, the manufacturing companies listed on the IDX were diversified companies. The results obtained through descriptive statistical analysis showed that company size was usually quite large as measured by total assets and market value of equity with mean values of IDR25,880 Million and IDR44,232 Million, respectively. 
Table 2. Descriptive statisics for sample data 2011-2014 ( $\mathrm{N}=88)$

\begin{tabular}{lllll}
\hline & Minimum & Maximum & Mean & Std. Deviation \\
\hline TOBINS Q & TOBINS Q & 17.9351 & 17.9351 & 17.9351 \\
CSR & CSR & 0.3846 & 0.3846 & 0.3846 \\
HISales & HISales & 0.9973 & 0.9973 & 0.9973 \\
NoSegment & NoSegment & 6.0 & 6.0 & 6.0 \\
Asset(Million IDR) & Asset(Million IDR) & 236,029 & 236,029 & 236,029 \\
MVE(Million IDR) & MVE(Million IDR) & 310,445 & 310,445 & 310,445 \\
\hline
\end{tabular}

Table 3. Results of multicollinearity test:

Variance Inflation Factor (VIF) and Tolerance (TOL)

\begin{tabular}{lcc}
\hline & VIF & TOL \\
\hline SCR & 1.220 & 0.819 \\
HISales & 1.343 & 0.745 \\
NoSegment & 1.632 & 0.613 \\
LnAssets & 8.068 & 0.124 \\
LnMVE & 7.926 & 0.126 \\
\hline
\end{tabular}

Table 4. Results of Regression Model

\begin{tabular}{|c|c|c|c|c|}
\hline \multirow[t]{2}{*}{ Model } & \multicolumn{2}{|c|}{ Unstandardized Coefficients } & \multirow[t]{2}{*}{ Model } & \multirow[t]{2}{*}{ Std. Deviation } \\
\hline & B & Std. Error & & \\
\hline (Constant) & 1.261 & 0.742 & 1.698 & 0.093 \\
\hline CSR & -0.926 & 0.573 & -1.615 & 0.110 \\
\hline HISales & 0.668 & 0.267 & 2.506 & $0.014 * *$ \\
\hline NoSegmen & 0.056 & 0.048 & 1.168 & 0.246 \\
\hline LnAsset & $-0,931$ & 0.065 & -14.416 & $0.000 * * *$ \\
\hline LnMVE & 0,939 & 0.052 & 18.219 & $0.000 * * *$ \\
\hline
\end{tabular}

\subsection{The Regression results}

A few assumptions need to be checked prior to the main modeling. The data was normally distributed since the Kolmogorov-SmirnovZ was insignificant with a p-value 0.092. Multicollinearity was also assessed. According to the analyses reported in Table 3, there was no multicollinearity in this study because all the independent variables had variance inflation factor (VIF) values less than 10 and their Tolerance statistics (TOL) values were more than 0.10 and less than 1. According to Gujarati (1995), the higher the VIF, the higher the collinearity among independent variables.

This study also found that there is no autocorrelation because the Durbin-Watson value of 2.030 is within the range between 1.7732 and 2.2268. Additionally, the scatter plot showed no clear pattern, which means that there is no heteroscedasticity in this study.Table 4 shows the regression results.

This study finds that corporate social responsibility (CSR) did not affect Tobin's Q ( $a 1=-0.926$, $\mathrm{t}=-1.615, \mathrm{p}=0.110$ ). Herfindahl index by sales had a significant effect on Tobin's $\mathrm{Q}$ with its coefficients a $2=0.668, \mathrm{t}=2.506, \mathrm{p}=0.29$ while the number of segments $(\mathrm{a} 3=0.056, \mathrm{t}=1.168$, $\mathrm{p}=0.246$ ) was not statistically related to Tobin's $\mathrm{Q}$ since its probability value was over 0.05 . This indicates that diversification of business as measured in the Herfindahl index by sales (HISales) was a determinant of company value in IDX but the number of business segments 
wasn't. Furthermore, the natural log of total assets and the natural log of market value of equity had significant effect on Tobin's $Q$ with their respective coefficients a4 $=-0.931, t=-14.416, p$ $=0.00$ and $\mathrm{a} 5=0.052, \mathrm{t}=18.219, \mathrm{p}=0.00$. Nevertheless, taken collectively, the independent variables have a significant effect on the Tobin's Q at 0.01 level with an F-value of 78.699 and adjusted R-square of 0.824 . 82.4\% of the variation in Tobin's Q could be explained by CSR, business diversification and, company size and the remaining $17.6 \%$ could be explained by other variables not included in this study.

\section{Discussion}

\subsection{H1: Corporate social responsibility positively and significantly affects company value.}

Corporate social responsibility (CSR) has a negative and insignificant influence on Tobin's Q (company value), so the first hyphotesis was rejected. Normally, good CSR is associated with high company value through expertise in managing the company. However, this was not proven for the manufacturing companies listed on the IDX. A good CSR could indicate that the company was better than others. CSR could also reduce information asymmetry and could guarantee the company's prospects in the future (Rahayu, 2015). Nevertheless, this is not applicable to the manufacturing companies listed on the IDX.

\subsection{H2: Business diversification (HiSales) has a positive and significant effect upon company value.}

The findings of the study showed that Herfindahl index by sales as a measure of diversification had a significant effect upon Tobin's $Q$ at 0.05 level $(p$-value $=0.014)$ with a positive coefficient. Therefore, the second hyphotesis was accepted. This means that manufacturing companies listed on the IDX could reap benefits from business diversification. The agency conflict in which managers could diversify businesses for on their own interests does not seem to be applicable to the manufacturing companies listed on the IDX. The internal capital market could finance other divisions and contribute to company value; this seems to have occurred among the manufacturing companies listed on the IDX as seen in the positive relationship between diversification of business and company value. This result supports Khanna and Palepu (1997), Scharfstein and Stein (1996), Stein (1997), Weston (1970), and Williamson (1970, 1975, 1985), who found that diversification of business in emerging capital markets increased company value.

\subsection{H3: Business diversification (NoSegment) is related to company value.}

The results indicate that third hypothesis is rejected since the number of business segments as a measure of business diversification had a positive but insignificant influence on Tobin's Q. The positive relationship indicates that a company could exploit the benefits of business diversification, which include synergy of assets across divisions, greater debt capacity, and tax shield. When a diversified company uses more debt, the company incurs interest expense . Such expenses can become a tax shield that could reduce a company's income tax. Moreover, a larger number of businesses means a more diversified company, which can also increase company value due to greater access to cheaper funds from internal capital markets. However, these results were statistically insignificant for the manufacturing companies listed on the IDX. This finding is not consistent with the works of Khanna and Palepu (1997), Santalo and Becerra (2008), Scharfstein and Stein (1996), Stein (1997), Weston (1970), and Williamson 
$(1970,1975,1985)$, who found that diversification in emerging capital markets significantly contributes to company value.

\subsection{H4: Company size (LnAssets) positively and significantly influences company value.}

The results show that size, which was measured by the natural log of total assets, has a negative and significant contribution to Tobin's Q. The negative sign of the coefficient $(-0,931)$ is not consistent with the hypothesis, so this study rejects hyphotesis 4 . This indicates that managers enlarge company size for their own interests rather than the shareholders' interest. In addition, conflicts of interest between agent (manager) and principal could also be associated with the asymmetric information problem where a manager is better informed about the company's current workings and future prospects. In a large company, information asymmetry might be high; as a result, it increases agency conflicts and reduces Tobin's Q. At the same time, larger companies may find it more difficult to monitor their managers (Yermack, 1996), which leads to high agency costs, thus reducing company value (Jensen \& Meckling, 1976).

\subsection{H5: Company size (LnMVE) has a positive and significant influence upon company value.}

Nevertheless, according to MVE, company size positively and significantly influences Tobin's Q. Hence, Hypothesis 5 can be accepted. The result shows a positive coefficient between company size and company value, which implies that larger company size would increase company value. This finding indicates that manufacturing companies listed on the IDX could reap the benefits of larger company size such as more skilled managers and employees as well as greater specialization, which could probably generate returns. This condition causes an increase in company value (Driffield et al., 2007; Gupta, 1969; Lang \& Stultz, 1994; Smith \& Watts, 1992). Additionally, it is assumed that a large company is more established has professional managers, and possesses employees with good levels of knowledge, skill and ability, which contribute to company value. Therefore, company size is a significant determinant of company value for manufacturing companies listed on the IDX. This result is consistent with previous studies that found size to have a positive and significant impact upon company value (Awwalia, 2014; Chakrabarti et al., 2007; Chen \& Ho, 2000; Kumar, 2005; Mickkelson et al., 1997; Ming \& Gee, 2008; Serrano-Cinca et al., 2007; Zeitun \& Tian, 2007). Investors associate company size with better value. The finding is not consistent with the implication stated in the agency theory, where it is rather difficult for shareholders to monitor the top management in a large company.

The findings of this study show that if size was represented by accounting variables, the negative sign runs contrary to expectations; but if the proxy used was based on market variablse, it returns the expected sign.

\section{Conclusion}

The results showed that business diversification (as proxied with the Herfindahl index by sales) and company size (as measured by total assets and market value of equity) were determinants of company value for manufacturing companies listed on the IDX. Other variables such as CSR and diversification, which are manifested in the number of business segments, do not affect company value. Based on these findings, it can be inferred that large companies are associated 
with an increase in company value. This is probably due to the fact that larger companies have generally more effective management arising from greater economies of scale, more skilled managers, greater specialization, and easier access to funds. The sample used in this study is limited to manufacturing companies. Hence, further studies might be oriented to look into other sectors and use other variables. Future research could also use related and unrelated diversification and see their influence upon company value.

\section{References}

Aggarwal, P.(2013), Relationship between environmental responsibility and financial performance of firm: a literature review, IOSR Journal of Business and Management, 13(1), 13-22.

Barnett, M.L.and Salomon, R.M. (2011) Does it pay to be really good? Addressing the shape of the relationship between social and financial performance, Strategic Management Journal,. Available at SSRN: http://ssrn.com/abstract=1860985

Berger, A. N., \& Humphrey, D. B. (1992). Megamergers in banking and the use of cost efficiency as an antitrust defense. The Antitrust Bulletin, Fall, 541-600.

Berger, P. G., \& Ofek, E. (1995). Diversification's effect on firm value. The Journal of Finance, 9(2 April), 39-65.

Bidhari, S.C., Salim, U., and Aisjah S., (2013) Effect of corporate social responsibility information disclosure on financial performance and firm value in banking industry listed at Indonesia stock exchange, European Journal of Business and Management, 5(18), 39-46.

Chakrabarti, A., Singh, K., \& Mahmood, I. (2007). Diversificattion and performance: Evidence from Asian firms. Strategic Management Journal, 28, 101-120.

Chen, S. S., \& Ho, K. W. (2000). Corporate diversification, ownership structure, and firm value: The Singapore evidence. International Review of Financial Analysis, 9, 315-326.

Driffield, N., Mahambare, V., \& Pal, S. (2007). How does ownership structure affect capital structure and firm value? Economics of Transition, 15(3), 535-573.

Freeman, R.E. 1984) Strategic management: a stakeholder approach, Boston: Pitman.

Freeman, R.E. (2001), Stakeholder theory of the modern corporation, Business Ethics, Vol.3, 38-48. Ghelli, C., (2010), Corporate social responsibility and financila performance: an empirical evidence, master thesis, Copenhagen Business School, Frederiksberg, Denmark, 2013

Gupta, M. C.(1969). The effect of size, growth, and industry on the financial structure of manufacturing companies. Journal of Finance, 24, 517-529.

Gujarati, D. N. (1995). Basic econometrics. Newyork: McGraw-hill. 
Ho, V.H., (2010), Enlightened shareholder value: corporate governance beyond the shareholderstakeholder divide, The Journal of Corporation Law, 36(1), 59-112.

Jensen, M. C., \& Meckling, W. H. (1976). Managerial behaviour, agency cost, and ownership structure Journal of Financial Economic 3, 305-360.

Khanna, T., \& Palepu, K. (2000). Why focuses strategy maybe wrong for emerging market? . Harvard Business Review July-August, 41-51.

Kock, C., \& Guillen, M. F. (2001). Strategy and structure in developing countries: Business groups as an evolutionary response to opportunities for unrelated diversification. Industrial and Corporate Change, 10(1), 77-113.

Kumar, J. (2005). Agency theory and firm value in India. Indira Gandhi institute of development research.

Lang, L. H. P., \& Stultz, R. M. (1994). Tobin's q, corporate diversification and firm performance. Journal of Political Economy, 102, 1248-1280.

Li, J., Lam, K., Qian, G., \& Fang, Y. (2006). The effects of institutional ownership on corporate governance and performance: An empirical assessment in Hong Kong. Management International Review, 46(3), 259-276.

Lins, K., V., \& Servaes, H. (1999). International evidence on the value of corporate diversification. The Journal of Finance, 54(6), 2215-2230.

Lins, K., V., \& Servaes, H. (2002). Is corporate diversification beneficial in emerging markets? . Financial Management, Summer, 5-9.

Margolis, J.D., Elfenbein, H.A. and Walsh J.P. (2009), Does it pay to be good... and does it matter? A meta-analysis of the relationship between corporate social and financial performance, Working Paper, Harvard Business School.

Mitton, T. (2002). A cross-firm analysis of impact of corporate governance on the East Asian financial crisis. Journal of Financial Economics, 64, 215-241.

Scharfstein, D. S., \& Stein, J. (1996). The dark side of internal capital markets: Divisional rent-seeking and inefficient investment. Unpublished Working paper. MIT.

Serrano-Cinca, C., Fuertes-Calle, Y., \& Gutierrez-Nieto, B. (2007). Online reporting by banks: a structural modelling approach. Online Information Review, 31(3), 310-332.

Smith, C., \& Watts (1992). The investment opportunity set and corporate financing, dividend and compensation policy. Journal of Financial Economics, 32, 263-292.

Suchman, M.C. (1995), Managing legitimacy: strategic and institutional approach, Academy of Management Review, 20(3), 571-610. 
Tilakasiri, K.K. (2012), Corporate social responsibility and company performance: evidence from Sri Lanka, doctoral thesis, Victoria University, Melbourne..

Titman, S., \& Wessels, R. (1988). The determinants of capital structure choice Journal of Finance, $4(1), 1-20$.

Vijfvinkel, S., Bouman, N.and Hessels, J. (2011), Environmental sustainability and financial performance of SMEs, EIM Research Reports.

Visser, W. , Matten, D. , Pohl, M., and Tolhurst, N. , (2010), The A to Z of corporate social responsibility, United Kingdom: Wiley.

Watts, P. and Holme, R. (2000) Meeting changing expectations: corporate social responsibility, Working group paper,London: Red Letter Design.

Susilowati, K.D.S. (2013) Entrepreneur's perspective on corporate social responsibility: a case in Indonesia, Proc. of 8th Asian Business Research Conference, Bangkok, Thailand, 1-18.

Williamson, O., E. (1970). Corporate control and business behaviour: An inquiry into the effect of organizational form on enterprise behaviour. Englewood Cliffs, NJ Prentice-Hall.

Williamson, O., E. (1975). Markets and hierarchies. New York: Free press.

Williamson, O., E. (1985). The economics institution of capitalism: Firms, markets, relational contracting. New York: Free press.

Yermack, D. (1996). Higher market value of companies with a small board of directors. Journal of Financial Economics, 40, 185-211. 